\title{
Dynamics and bacterial colonization of microaggregates in a large mesotrophic lake
}

\author{
Till Brachvogel ${ }^{1}$, Bernhard Schweitzer $^{1}$, Meinhard Simon $^{2, *}$ \\ ${ }^{1}$ Limnological Institute, University of Constance, 78457 Konstanz, Germany \\ ${ }^{2}$ Institute for Chemistry and Biology of the Marine Environment, University of Oldenburg, PO Box 2503, \\ 26111 Oldenburg, Germany
}

\begin{abstract}
We studied the occurrence and dynamics of transparent exopolymer particles (TEP) and 4'-6'-diamidino-2-phenylindole (DAPI)-stained microaggregates (MA) and the bacterial colonization of the latter by fluorescence in situ hybridization with rRNA-targeted oligonucleotides in Lake Constance, Germany, from June to December 1996. MA were categorized into the size classes 8 to 20 , 20 to 60 and $>60 \mu \mathrm{m}$. Total abundance of TEP varied between 71 and $2554 \mathrm{ml}^{-1}$ and that of MA between 310 and $1526 \mathrm{ml}^{-1}$ with the largest proportion in the size class 8 to $20 \mu \mathrm{m}\left(140\right.$ to $\left.959 \mathrm{ml}^{-1}\right)$. Numbers of TEP and of MA >60 $\mu \mathrm{m}$, never exceeding $100 \mathrm{ml}^{-1}$, decreased with depth and were correlated to the biomass of total phytoplankton, diatoms, chrysophytes and dinoflagellates. Numbers of the smaller-sized MA did not systematically decrease with depth. Four types of DAPI-stained MA were identified: aggregates composed of bacterial and of cyanobacterial colonies, aggregates fluorescing yellow (DAPI yellow particles), and phytoplankton and zooplankton fragments fluorescing faintly blue after DAPI staining. The latter and DAPI yellow particles were most abundant. The majority of MA was densely colonized by bacteria. At least $20 \%$ of the DAPI-stainable cells were detected by the Bacteria-specific probe EUB338 and a mean between 44 and $56 \%$ of the various types of MA. $\beta$-Proteobacteria dominated aggregates composed of remains of diatoms and often also on fragments. On DAPI yellow particles bacteria of this phylogenetic lineage and the Cytophaga/Flavobacteria cluster were equally abundant. $\gamma$-Proteobacteria usually constituted only minor proportions except on fragments of Dinobryon spp. and of zooplankton origin on which they constituted up to $62 \%$ of the DAPI-stainable cells. $\alpha$-Proteobacteria were not detected at all. Together, all group-specific probes constituted $>95 \%$ of the bacteria detected by the EUB338 probe on MA except for bacterial aggregates on which only $59 \%$ were detected. The different spatio-temporal dynamics of TEP and MA and the bacterial colonization of the latter suggested that TEP and MA > $60 \mu \mathrm{m}$ were early decomposition products mainly of diatoms and other algae whereas smaller MA were more degraded stages of detrital particulate organic matter.
\end{abstract}

KEY WORDS: Microaggregates · Transparent exopolymer particles · Bacteria $\cdot$ In situ hybridization · Lake Constance

Resale or republication not permitted without written consent of the publisher

\section{INTRODUCTION}

In pelagic ecosystems the primary source of particulate organic matter (POM) is phytoplankton, forming autotrophic living particles of various size classes. During the transfer processes within the food web much of the energy and organic carbon of these living particles

${ }^{*}$ Corresponding author. E-mail: m.simon@icbm.de is channeled through various trophic levels but a considerable amount is released as dissolved organic matter or transformed into dead matter, i.e., detrital POM. The occurrence and size distribution of detrital POM span a wide range, from submicrometer particles to microparticles and macroscopic aggregates exceeding a few centimeters (Alldredge \& Silver 1988, Koike et al. 1990, Herndl 1992, Alldredge et al. 1993, Wells \& Goldberg 1994, Long \& Azam 1996). 
The formation and fate of macroscopic detrital aggregates and their role in the cycling and flux of energy and elements and in the downward flux in pelagic ecosystems have been studied extensively during the last decade. Many studies have shown their importance for the sinking flux and that key processes of nutrient recycling are mediated by the associated microflora (e.g., Alldredge \& Silver 1988, Herndl 1992, Smith et al. 1992, Grossart et al. 1997, Grossart \& Simon 1998a). They are formed from the ambient POM, mainly senescent phytoplankton and predominantly diatoms (Alldredge \& Silver 1988, Alldredge \& Gotschalk 1989, Kiørboe et al. 1994, Grossart et al. 1997). A substantial amount of these aggregates sinks out of the euphotic zone and their labile components are decomposed during sinking. They are partly respired or solubilized and released into the surrounding water (Smith et al. 1992, Ploug et al. 1997, 1999, Grossart \& Simon 1998b, Berman et al. 1999) but it is unclear whether aggregates sinking through deep, i.e. $>100 \mathrm{~m}$, water bodies scavenge other microparticles or disintegrate, at least partly, to smaller particles before they reach the sediment surface.

The formation and significance of particles of the smallest size classes of POM, the micrometer and submicrometer range and at the transition to the colloidal fraction of organic matter, are less well understood (Kepkay 1994). Some of these particles, the abundance of which can exceed that of free-living bacteria, were shown to be protozoan fecal material of liposome-like structures, including also proteins, but being fairly resistant to bacterial decomposition (Nagata \& Kirchman 1997). From other particles, mainly the distribution in space and time and some morphological characteristics are known but nothing about their function and general significance in pelagic ecosystems (Koike et al. 1990, Wells \& Goldberg 1994).

In the size class of a few to 100 or $200 \mu \mathrm{m}, 3$ different types of detrital microparticles abundant in pelagic waters have been recently identified. Alldredge et al. (1993) described transparent exopolymer particles (TEP), consisting of acidic polysaccharides. TEP were shown to be secreted mainly by senescent marine and limnetic phytoplankton, often densely colonized by bacteria, and important in the formation of macroscopic aggregates (Alldredge et al. 1993, Passow et al. 1994, Logan et al. 1995, Grossart et al. 1997, 1998, Worm \& Søndergaard 1998). Mostajir et al. (1995a,b) found microparticles that fluoresce yellow after staining with 4'-6'-diamidino-2-phenylindole (DAPI) and were abundant in Mediterranean coastal waters (DAPI yellow particles). The spatio-temporal distribution of these microparticles was rather independent from chlorophyll but that of its fraction $<10 \mu \mathrm{m}$ covaried with bacteria, heterotrophic flagellates and ciliates.
The origin and significance of the DAPI yellow particles are largely open. Long \& Azam (1996) reported on a new class of protein-containing microparticles in marine waters stainable with Coomassie brilliant blue that were more abundant than TEP and partly colonized by bacteria. A better understanding of the significance of the latter 2 classes of microparticles in pelagic ecosystems is very important, also with respect to their origin and fate and the occurrence of macroscopic aggregates and TEP.

We studied the spatio-temporal dynamics and component particle composition of DAPI-stained particles and microaggregates (MA) in the size range of 8 to $150 \mu \mathrm{m}$ together with those of TEP in mesotrophic and deep Lake Constance, Germany. In addition, we examined the bacterial colonization of the DAPIstained particles by fluorescent in situ hybridization with rRNA-targeted oligonucleotides of various specificity. The results show pronounced differences of the spatio-temporal dynamics of TEP and DAPI-stained MA. Four different types of the latter occurred: bacterial MA, cyanobacterial MA, DAPI yellow particles, and detrital aggregates composed of phytoplankton and zooplankton debris. Their vertical distribution and bacterial colonization indicated that DAPI-stained MA were decomposition stages of phyto- and zooplankton and of macroscopic aggregates rather than source particles of the latter.

\section{MATERIAL AND METHODS}

Lake Constance is a mesotrophic and warm-monomictic prealpine lake with a surface area of $472 \mathrm{~km}^{2}$ and maximum and mean depths of 253 and $101 \mathrm{~m}$, respectively. The lake has been studied intensively in the recent past (e.g. Gaedke 1998, Güde \& Gries 1998, Simon et al. 1998), also with respect to the significance of lake snow aggregates (e.g. Grossart \& Simon 1993, Weiss et al. 1996, Grossart et al 1997, Schweitzer et al. 2001). Between June and October 1996 samples from 6, 10, 15, 20, 30, 50 and $100 \mathrm{~m}$ depths were collected weekly with van Dorn bottles at the center of Lake Überlingen, a north-western fjord-like arm of Lake Constance with maximum and mean depths of 147 and $90 \mathrm{~m}$, respectively. Samples for DAPI-stained MA (see below) were taken from 6 , $15,30,50$ and $100 \mathrm{~m}$ depths and those for TEP from 6 , $10,20,30$ and $50 \mathrm{~m}$ and 1 to $3 \mathrm{~d}$ after those for MA. A final sampling was carried out on 18 December 1996. Samples were carefully withdrawn into opaque clean 51 plastic carboys and processed further in the laboratory within $2 \mathrm{~h}$.

Abundance, size classes and composition of MA. Samples of $150 \mathrm{ml}$ were gravity-filtered through black 
$5.0 \mu \mathrm{m}$ pore size Nuclepore filters (47 $\mathrm{mm}$ diameter). On the filters, samples were stained for 5 min with DAPI (1 mg $100 \mathrm{ml}^{-1}$ ) rinsed with Milli-Q water, embedded in silicon oil on a glass slide and examined under an epifluorescence microscope (Labophot 2A, Nikon) at a magnification of $100 \times$ or $400 \times$. In 10 view fields at least $100 \mathrm{MA}$ were counted and sized with an ocular grid into size classes of 8 to 20,20 to 60 and $>60 \mu \mathrm{m}$. The upper limit of the size class $>60 \mu \mathrm{m}$ was $150 \mu \mathrm{m}$. Irregularly shaped MA were categorized according to their longest dimension. To examine the composition and the relative abundance of the different types of MA, on 4 July, 13 August, 19 September and 15 October, $100 \mathrm{MA}$ of the size classes 8 to 20 and 20 to $60 \mu \mathrm{m}$ were examined according to their component particle composition. MA $>60 \mu \mathrm{m}$ exhibited a complex composition not allowing a clear-cut categorization. In addition, the colonization of MA by bacteria was assessed at $1000 \times$ magnification.

TEP. The abundance of TEP was determined according to Logan et al. (1994). Briefly, $3 \mathrm{ml}$ was filtered onto a $0.2 \mu \mathrm{m}$ Nuclepore filter (25 mm diameter), placed on a $0.45 \mu \mathrm{m}$ nitrocellulose backing filter, and stained with $0.5 \mathrm{ml}$ of a $0.03 \%$ particle-free solution of alcian blue for $30 \mathrm{~s}$ (Fluka, stock solution of $1 \%$ alcian blue in $3 \%$ acetic acid). After withdrawing the stain by gentle vacuum (0.1 bar) the Nuclepore filter was transferred onto a Cyto-clear slide (Poretrics Corp.) covered with a drop of silicon oil and a cover slide. The filtered sample was viewed and enumerated under brightfield illumination with a Nikon microscope (Labophot 2A) at $400 \times$ magnification. The coefficient of variation (standard deviation/mean) usually was 10 to $20 \%$.

Bacterial colonization of MA. The composition of the bacterial community on MA was determined by in situ hybridization with fluorescently labeled rRNA-targeted oligonucleotides between 18 July and 28 August on samples from $15 \mathrm{~m}$. In addition, on 8 and 13 August a sample from $50 \mathrm{~m}$ and on the latter date also from $6 \mathrm{~m}$ was hybridized. We used probes specific for Bacteria (EUB338, Amann et al. 1990), the $\alpha-, \beta-$, and $\gamma$ Proteobacteria (ALF1b, BET42a, GAM42a; Manz et al. 1992) and the cluster Cytophaga/Flavobacteria (CF319a, Manz et al. 1996). The probes were linked to the fluorochrome 5,(6)-carboxyfluorescein- $N$-hydroxysuccinimide ester (Fluos) or Cy3 (derivate of succinimidester Cy3 of a cyanine). For in situ hybridization the procedures outlined in Manz et al. (1992, 1996) were applied but modified as follows. Samples of $150 \mathrm{ml}$ were gravity-filtered onto black $5.0 \mu \mathrm{m}, 47 \mathrm{~mm}$ Nuclepore filters and overlayed by $5 \mathrm{ml}$ of a $4 \%$ paraformaldehyde-phosphate buffer saline, $\mathrm{pH}$ 7.2, for $30 \mathrm{~min}$ for fixation. Thereafter, the fixative was removed by gentle vacuum and the samples rinsed with $4 \mathrm{ml}$ each of phosphate-buffered saline and of Milli-Q water. The dried filters were stored at $4^{\circ} \mathrm{C}$ until further processing within a few days. In situ hybridization was performed at $46^{\circ} \mathrm{C}$ for 90 min in preheated hybridization chambers mounted on a $25 \mathrm{~mm}$ filtration manifold. Therefore, each filter was cut into quarters that were put on top of a $0.45 \mu \mathrm{m}$ cellulose nitrate filter on the manifold. To each filter quarter, $10 \mu \mathrm{l}$ of the hybridization buffer was applied. It contained $0.9 \mathrm{M} \mathrm{NaCl}$ and formamide at a concentration of $20 \%$ (EUB338, ALF1b) or $35 \%$ (BET42a, GAM42a, CF318a), 20 mM Tris/HCl ( $\mathrm{pH} 7.4), 0.01 \%$ sodium dodecyl sulfate and the probe in a concentration of $2.5 \mathrm{ng} \mathrm{ul}^{-1}$, each. Probes BET42a and GAM42a were used with a competitor oligonucleotide (Manz et al. 1992, Snaidr et al. 1997). To stop hybridization, the filter quarters were overlayed for 15 min at $46^{\circ} \mathrm{C}$ with $3 \mathrm{ml}$ of washing buffer, containing $180 \mathrm{mM}$ (20\% formamide) or $40 \mathrm{mM}$ (35\% formamide) $\mathrm{NaCl}$ and $0.01 \%$ sodium dodecyl sulfate. Thereafter, the washing buffer was removed by filtration, and the filters were rinsed with distilled water and stained with DAPI $(0.01 \%)$. Finally, they were embedded in Cityfluor (Chemical Laboratory, University of Kent, UK) on glass slides and covered with cover slides. The hybridized samples were visualized by a Nikon epifluorescence microscope equipped with the filter sets UV2A (DAPI, Nikon) and B-2A (Fluos, Nikon) and XF32 NM198 (Cy3, Omega Optical Inc.).

Chlorophyll and phytoplankton. Chlorophyll a was determined spectrophotometrically after hot ethanol extraction. Phytoplankton was analyzed in samples integrated between 0 and $20 \mathrm{~m}$ by 10 hauls with a $2 \mathrm{~m}$ long tube sampler. Phytoplankton was classified, sized and quantified by inverted microscopy. For determining fresh weight, biovolumes were calculated for individual species and multiplied by their cell numbers assuming a density of $1 \mathrm{~g} \mathrm{ml}^{-1}$. For further details see Gaedke (1998). Even though biomass values are integrated from 0 to $20 \mathrm{~m},>70 \%$ of the phytoplankton biomass occurred at a depth of between 0 and $8 \mathrm{~m}$.

\section{RESULTS}

The study started in June when the lake became thermally stratified with near-surface temperatures exceeding $15^{\circ} \mathrm{C}$. Highest temperatures of 20 to $21^{\circ} \mathrm{C}$ prevailed from June to August. The epilimnion was $6 \mathrm{~m}$ thick in June and deepened to $12 \mathrm{~m}$ until September before it started to erode gradually. In early June, the clear water-phase was established, which follows the phytoplankton spring bloom regularly due to heavy grazing by daphnids. In July and August, 2 phytoplankton blooms occurred; the first one in July was dominated by Dinobryon spp. and Ceratium hirundinella, and that in August by colony-forming 
diatoms such as Fragilaria crotonensis, Asterionella formosa and Tabellaria fenestrata (Fig. 1A). In early September another bloom of Dinobryon spp. followed. Chlorophyll a did not properly reflect the development of the phytoplankton blooms because it only roughly followed the dynamics of the phytoplankton fresh weight. It indicated, however, that the diatoms settled out of the euphotic zone between mid-August and early September, as shown by the time-lags between the chlorophyll maxima at 6, 15, and $30 \mathrm{~m}$ (Fig. 1B).

\section{Abundance, size classes and composition of TEP and DAPI-stained MA}

The abundance of TEP varied greatly in space and time, ranging from 71 to $2554 \mathrm{ml}^{-1}$ (Fig. 2) with seasonal means between 440 and $859 \mathrm{ml}^{-1}$ in the various depths (Table 1). Numbers were highest in midAugust at $6 \mathrm{~m}$ and in the first half of September between 6 and $30 \mathrm{~m}$. In late September, TEP abundance decreased sharply throughout the water col-

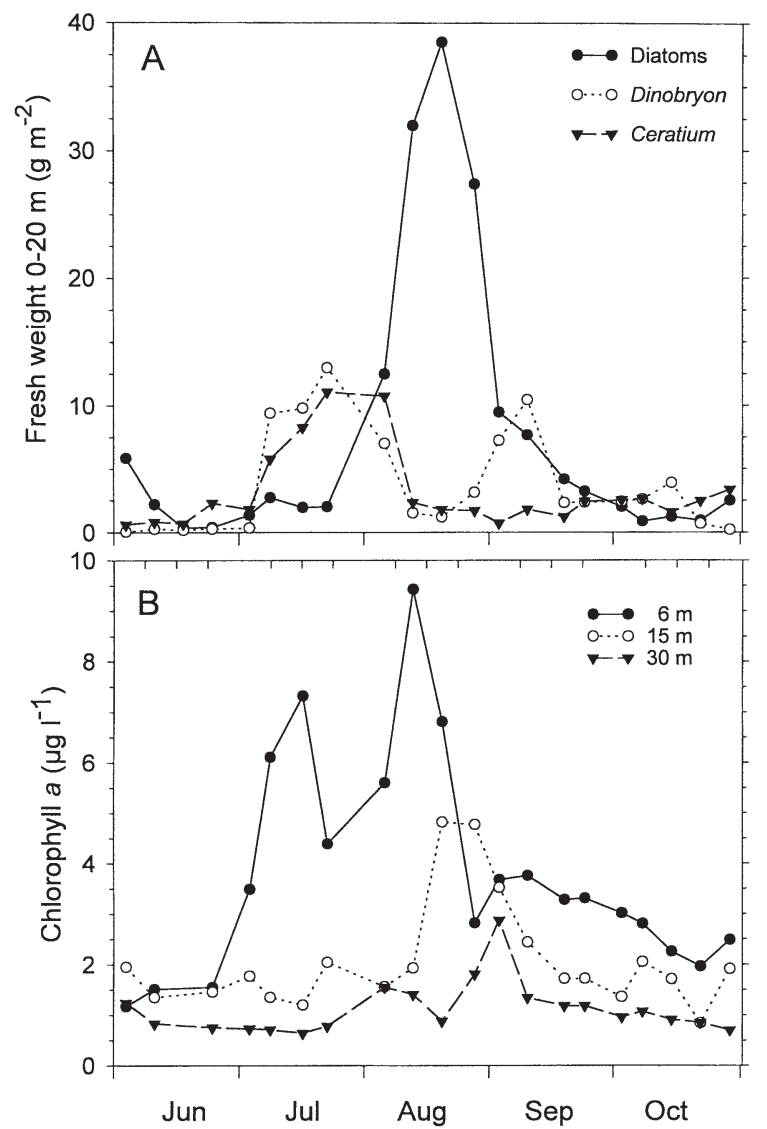

Fig. 1. Fresh weight of (A) diatoms, Dinobryon spp. and Ceratium hirundinella and (B) chlorophyll a concentrations at 6, 15 and $30 \mathrm{~m}$ in Lake Constance in 1996. Fresh weights are integrated values from 0 to $20 \mathrm{~m}$ umn. From mid-August until mid-September, TEP abundance decreased with depth, in particular between 20 and $30 \mathrm{~m}$ (Fig. 2). Linear regression analyses revealed significant correlations of TEP abundance at $6 \mathrm{~m}$ with phytoplankton biomass and at 30 and $50 \mathrm{~m}$ with DAPI-stained MA in the size class 20 to $60 \mu \mathrm{m}$ (Table 2).

Numbers of DAPI-stained MA in the size class 8 to $20 \mu \mathrm{m}$ ranged between 140 and $959 \mathrm{ml}^{-1}$ (Fig. 3) and of MA in the size class 20 to $60 \mu \mathrm{m}$ between 88 and $525 \mathrm{ml}^{-1}$ (Fig. 2). During June and July numbers in the size class 8 to $20 \mu \mathrm{m}$ were significantly higher than those in the size class 20 to $60 \mu \mathrm{m}$ ( $t$-test, $\mathrm{p}<0.01)$. Between August and October at 6 and $15 \mathrm{~m}$ and in September at $30 \mathrm{~m}$ numbers in these 2 size classes, however, were not significantly different. Numbers of MA in the size class $>60 \mu \mathrm{m}$ were always lowest and did not exceed $100 \mathrm{ml}^{-1}$ (Fig. 3).

Total abundance of DAPI-stained MA as the sum of all 3 size classes varied between 310 and $1526 \mathrm{ml}^{-1}$. Total numbers of MA as the sum of DAPI-stained MA plus TEP ranged between $\sim 1000$ and $\sim 3500 \mathrm{ml}^{-1}$ at $6 \mathrm{~m}$ (mean $1552 \mathrm{ml}^{-1}$ ) and between $\sim 1000$ and $\sim 1900 \mathrm{ml}^{-1}$ at $50 \mathrm{~m}$ (mean $1176 \mathrm{ml}^{-1}$, Table 1). TEP as a percentage of total MA decreased from 55 to $40 \%$ between 6 and $50 \mathrm{~m}$. Because of the mutually exclusive staining techniques of TEP by alcian blue and of other MA by DAPI we cannot completely rule out that there was some overlap between the assessment of TEP and the other MA (see 'Discussion').

Linear regression analyses showed no significant correlation between MA $<60 \mu \mathrm{m}$ and TEP or phytoplankton parameters at 6 and $15 \mathrm{~m}$. MA $>60 \mu \mathrm{m}$ at $6 \mathrm{~m}$, however, were significantly correlated to the biomasses of Dinobryon sp. and Ceratium hinrundinella (Table 2). At $15 \mathrm{~m}$ depth, MA of the 3 size classes were significantly correlated among each other with the highest regression coefficient occurring for the periods of the phytoplankton blooms between July and September. At 30, 50 and $100 \mathrm{~m}$ the abundance of MA 20 to $60 \mu \mathrm{m}$ was significantly correlated to that of MA $>60 \mu \mathrm{m}$.

Four different types of DAPI-stained MA were identified according to their component particle composition: (1) bacteria of various morphologies aggregated into microcolonies and were surrounded by mucuslike material fluorescing faintly blue (bacterial aggregates); (2) cyanobacterial colonies such as Microcystis sp., in which other algal fragments were embedded; (3) detrital aggregates, fluorescing yellow and consisting often of a porous and granular structure in which diatom frustules or small fragments were embedded (DAPI yellow particles); and (4) fragments of algae and zooplankton, fluorescing faintly blue but never yellow and fairly heterogeneous in structure and composition 
(fragments). This categorization was possible only for the 2 smaller size classes because the $>60 \mu \mathrm{m}$ size class often consisted of complex aggregates that were difficult to ascribe to any of these categories. Aggregates in this size class, however, were taken into account with respect to their bacterial colonization (see below). With respect to the bacterial colonization, fragments of diatoms were separated from other algae and zooplankton (see below).

On all 4 dates when the composition of MA at $15 \mathrm{~m}$ was examined DAPI yellow particles dominated both size classes. Except on 13 August, these particles constituted at least 80 and $53 \%$ of total MA in the 2 size classes, respectively (Fig. 4A,B). Fragments of algae and zooplankton constituted proportions of 6 to $20 \%$ of MA in the size class 8 to $20 \mu \mathrm{m}$ and proportions of 20 to $29 \%$ in the larger size class. Bacterial aggregates were abundant only on 13 August constituting 43 and $37 \%$ of the 2 size classes, respectively. On the other dates, their proportion remained below $14 \%$. Cyanobacterial aggregates, which were recorded in the size class 8 to $20 \mu \mathrm{m}$ only on 19 September with a marginal share, constituted increasing proportions of 8 to $19 \%$ in the larger size class from 13 August to 15 October.

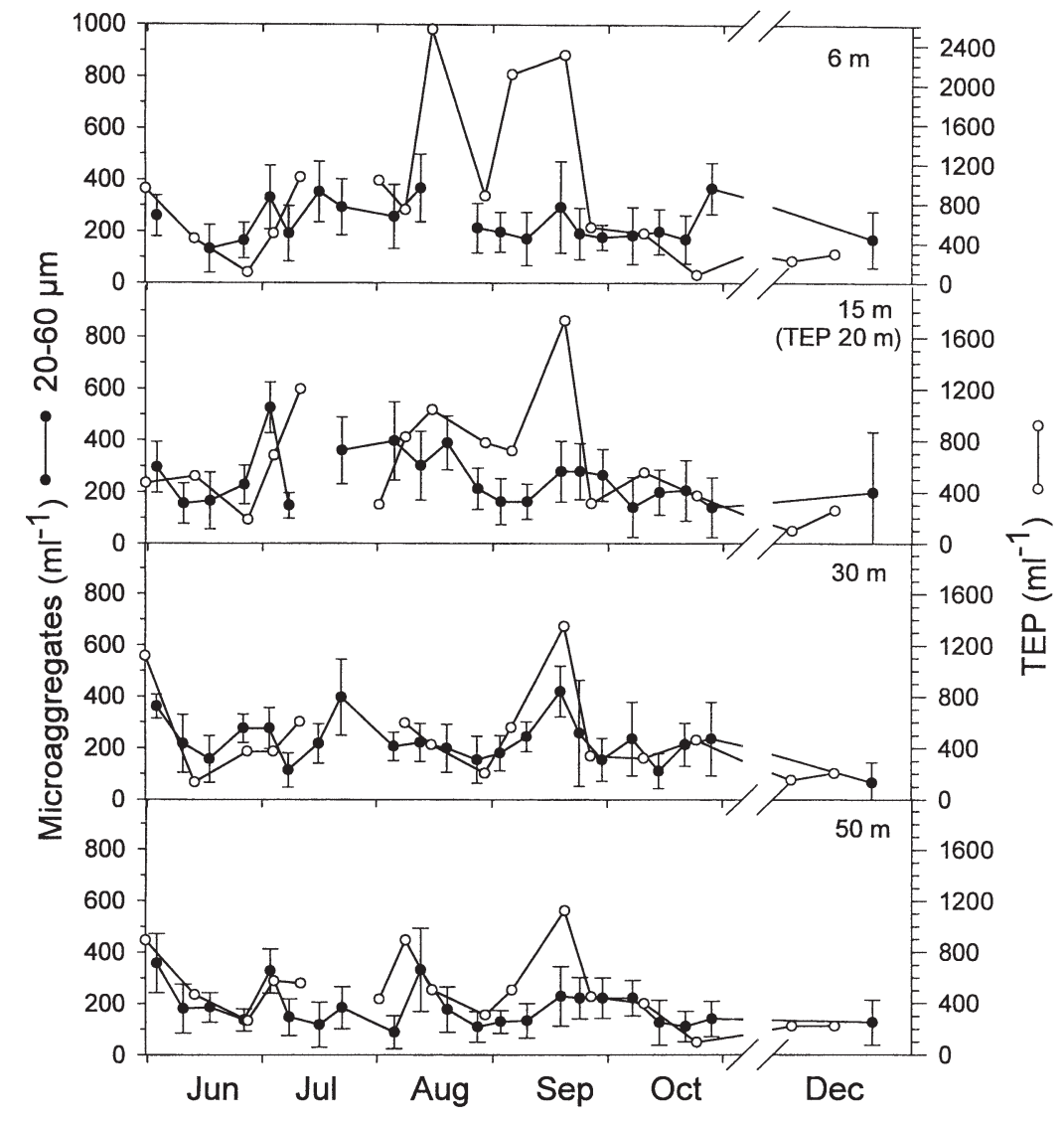

Fig. 2. Numbers of transparent exopolymer particles (TEP) and 4'-6'-diamidino-2-phenylindole (DAPI)-stained microaggregates $( \pm$ SD) of the size class 20 to $60 \mu \mathrm{m}$ at $6,15 / 20,30$ and $50 \mathrm{~m}$ depths in Lake Constance between June and December 1996. Samples for the enumeration of TEP were collected at $20 \mathrm{~m}$ and those for microaggregates at $15 \mathrm{~m}$

\section{Bacterial colonization of MA}

We enumerated the bacteria on the different types and size classes of DAPI-stained MA but not on TEP. Because there was no significant difference in the colonization structure among the various sampling dates, all numbers were pooled to calculate a mean bacterial colonization per aggregate type. Generally, the num-

Table 1. Mean numbers $\mathrm{ml}^{-1}( \pm \mathrm{SD})$ for the entire study period of transparent exopolymer particles (TEP) and 4'-6'-diamidino-2-phenylindole (DAPI)-stained microaggregates of the size classes 8 to 20,20 to 60 and $>60 \mu \mathrm{m}$ at $6,10,15,20$, 30, 50 and $100 \mathrm{~m}$. nd: not determined

\begin{tabular}{|lccccc|}
\hline \multirow{2}{*}{$\begin{array}{l}\text { Depth } \\
(\mathrm{m})\end{array}$} & TEP & \multicolumn{4}{c}{ Microaggregate size classes } \\
\hline 6 & & 8 to $20 \mu \mathrm{m}$ & 20 to $60 \mu \mathrm{m}$ & $>60 \mu \mathrm{m}$ & Total \\
10 & $859 \pm 740$ & $426 \pm 170$ & $234 \pm 73$ & $33 \pm 21$ & 693 \\
15 & $744 \pm 609$ & nd & nd & nd & nd \\
20 & nd & $475 \pm 182$ & $248 \pm 100$ & $29 \pm 16$ & 752 \\
30 & $603 \pm 411$ & nd & nd & nd & nd \\
50 & $440 \pm 334$ & $500 \pm 132$ & $223 \pm 86$ & $24 \pm 14$ & 747 \\
100 & $476 \pm 271$ & $502 \pm 154$ & $181 \pm 74$ & $17 \pm 14$ & 700 \\
& nd & $535 \pm 123$ & $207 \pm 87$ & $16 \pm 14$ & 758 \\
\hline
\end{tabular}

ber of bacteria per aggregate increased from the aggregate size classes 8 to $20 \mu \mathrm{m}$ to $>60 \mu \mathrm{m}$ (Table 3). Aggregates consisting exclusively of bacteria exhibited the highest numbers per aggregate whereas DAPI yellow particles, fragments, and cyanobacterial and diatom aggregates were colonized by significantly fewer bacteria $(t$-test, $\mathrm{p}<0.01)$. The increase in bacteria per aggregate was statistically significant on bacterial aggregates of the 3 size classes, on fragments of 8 to $20 \mu \mathrm{m}$ compared with those $>60 \mu \mathrm{m}$ and on Fragilaria aggregates of 20 to $60 \mu \mathrm{m}$ compared with those $>60 \mu \mathrm{m}$ ( $t$-test, $\mathrm{p}<0.01)$. Taking into account the abundance of MA ml-1 (see above) the numbers of bacteria per aggregate translate into total numbers of bacteria on DAPIstained MA in the range of 0.8 to $6.4 \times$ $10^{4} \mathrm{ml}^{-1}$ of lake water. On the basis of $\sim 1 \times 10^{6}$ to $\sim 6 \times 10^{6}$ free-living bacteria 
Table 2. Linear regression analysis of abundances of TEP and DAPI-stained microaggregates (MA) of various size classes and phytoplankton biomass parameters. $\mathrm{r}^{2}>0.25$ of significant correlations is given $(\mathrm{p}<0.01)$. Phytoplankton biomasses are integrated values between 0 and $20 \mathrm{~m}$. nd: not determined; ns: not significant

\begin{tabular}{|c|c|c|c|}
\hline \multirow{2}{*}{$\begin{array}{l}\text { Independent } \\
\text { variable }\end{array}$} & \multirow{2}{*}{$\begin{array}{c}\text { Dependent } \\
\text { variable }\end{array}$} & \multicolumn{2}{|c|}{$\mathrm{r}^{2}$} \\
\hline & & $\begin{array}{l}1 \text { Jun to } \\
18 \mathrm{Dec}\end{array}$ & $\begin{array}{l}1 \mathrm{Jul} \text { to } \\
19 \mathrm{Sep}\end{array}$ \\
\hline \multicolumn{4}{|l|}{$6 \mathrm{~m}$} \\
\hline Phytoplankton biomass & TEP & 0.30 & ns \\
\hline Dinobryon + Ceratium biomass & $\mathrm{MA}>60 \mu \mathrm{m}$ & 0.46 & nd \\
\hline Ceratium biomass & $\mathrm{MA}>60 \mu \mathrm{m}$ & 0.56 & nd \\
\hline \multicolumn{4}{|l|}{$15 \mathrm{~m}$} \\
\hline MA 8 to $20 \mu \mathrm{m}$ & MA 20-60 $\mu \mathrm{m}$ & 0.52 & 0.78 \\
\hline MA 8 to $20 \mu \mathrm{m}$ & $\mathrm{MA}>60 \mu \mathrm{m}$ & ns & 0.60 \\
\hline MA 20 to $60 \mu \mathrm{m}$ & $\mathrm{MA}>60 \mu \mathrm{m}$ & 0.32 & 0.63 \\
\hline \multicolumn{4}{|l|}{$30 \mathrm{~m}$} \\
\hline TEP & MA $20-60 \mu \mathrm{m}$ & 0.51 & 0.58 \\
\hline MA 20 to $60 \mu \mathrm{m}$ & $\mathrm{MA}>60 \mu \mathrm{m}$ & 0.36 & 0.49 \\
\hline \multicolumn{4}{|l|}{$50 \mathrm{~m}$} \\
\hline TEP & MA $20-60 \mu \mathrm{m}$ & 0.49 & 0.37 \\
\hline MA 20 to $60 \mu \mathrm{m}$ & $\mathrm{MA}>60 \mu \mathrm{m}$ & 0.48 & 0.88 \\
\hline \multicolumn{4}{|l|}{$100 \mathrm{~m}$} \\
\hline MA 20 to $60 \mu \mathrm{m}$ & $\mathrm{MA}>60 \mu \mathrm{m}$ & 0.67 & 0.75 \\
\hline
\end{tabular}

$\mathrm{ml}^{-1}$ (Simon et al. 1998), these numbers are equivalent to 0.5 to $3.4 \%$ of total numbers of bacteria.

Not all MA of each type, however, were visibly colonized by bacteria, but a larger proportion of aggregates in the size class 20 to $60 \mu \mathrm{m}$ was colonized than in the size class 8 to $20 \mu \mathrm{m}$. Fifty-one to $98 \%$ of the DAPI yellow particles were colonized by bacteria, also with higher proportions in the larger size class (Table 4) and more than $93 \%$ of the cyanobacterial aggregates in the size class 20 to $60 \mu \mathrm{m}$.

Between 7 and $96 \%$ of the DAPI-stainable cells on the MA were detected as Bacteria by the probe EUB338 (Fig. 5A). Particularly low values of $<10 \%$ were recorded on 20 August of fragments and cyanobacterial aggregates and on 28 August of the latter as well. On other types of aggregates and dates at least $21 \%$ and a mean of 44 to $56 \%$ of the DAPIstainable cells were detected as Bacteria (Table 5). In most cases $\beta$-Proteobacteria and cells of the Cytophaga/Flavobacteria cluster dominated the bacterial community on MA. Their proportions varied considerably and ranged from 8 to $78 \%$ of the DAPI-stainable cells, which equals 14 to $82 \%$ of Bacteria. $\beta$-Proteobacteria dominated diatom aggregates and algal and zooplankton fragments on 18 July, on 8, 13 and 20 August (Fig. 5B) and as a mean of all dates (Table 5). On bacterial aggregates and DAPI yellow particles, propor- tions of $\beta$-Proteobacteria and cells of the Cytophaga/Flavobacteria cluster did not differ significantly. $\gamma$-Proteobacteria usually occurred in substantially lower proportions on all types of MA than $\beta$-Proteobacteria and cells of the Cytophaga/Flavobacteria cluster. Except for algal fragments occurring between 25 July and 20 August and DAPI yellow particles on 28 August, their proportion remained below $20 \%$ and often below $5 \%$ of the DAPI-stainable cells, equivalent to 8 to $27 \%$ of the cells detected by probe EUB338. On 18 and 25 July during the prominent bloom of Dinobryon spp. many of the empty thecae of this algae were densely colonized by $\gamma$-Proteobacteria and, to a much lesser extent, by cells of the Cytophaga/Flavobacteria cluster. Hence, on the latter date on fragments at $15 \mathrm{~m}$ $\gamma$-Proteobacteria constituted $62 \%$ of the DAPI-stainable cells and $80 \%$ of the Bacteria (Fig. 5B). $\gamma$-Proteobacteria often also dominated zooplankton fragments. Detecting the fluorescent probe signals on cyanobacterial aggregates was particularly difficult due to the high autofluorescence of the cyanobacteria. Therefore, numbers of $\beta$ - and $\gamma$-Proteobacteria on these aggregates are available for only 2 dates but with very high standard errors. Because of the low detection rate of probe EUB338 on 20 August, detection rates of the group-specific probes were particularly high on this date, exceeding $100 \%$ of the EUB338 counts (Fig. 5B) but remaining well below the DAPI cell counts, also as the cumulative number of all 3 probes.

On 8 and 13 August the bacterial colonization of MA was also analyzed at 6 and $50 \mathrm{~m}$ but the general colonization patterns were not different from those of the other depths (data not shown). It was striking that we did not detect on any MA signals by the probe ALF1b

Table 3. Mean numbers of bacteria on different types and size classes of DAPI-stained microaggregates. nd: no or too few aggregates detected to calculate a mean

\begin{tabular}{|lccc|}
\hline Type & 8 to $20 \mu \mathrm{m}$ & 20 to $60 \mu \mathrm{m}$ & $>60 \mu \mathrm{m}$ \\
\hline Bacterial aggregates & $71 \pm 43$ & $312 \pm 218$ & $1064 \pm 661$ \\
DAPI yellow particles & $18 \pm 8$ & $31 \pm 19$ & $\mathrm{nd}$ \\
Algal or zooplankton fragments & $30 \pm 16$ & $51 \pm 36$ & $81 \pm 46$ \\
Cyanobacterial aggregates & nd & $45 \pm 29$ & $125 \pm 127$ \\
Fragilaria crotonensis & nd & $29 \pm 10$ & $115 \pm 66$ \\
Asterionella formosa and others & nd & $30 \pm 23$ & $86 \pm 52$ \\
\hline
\end{tabular}




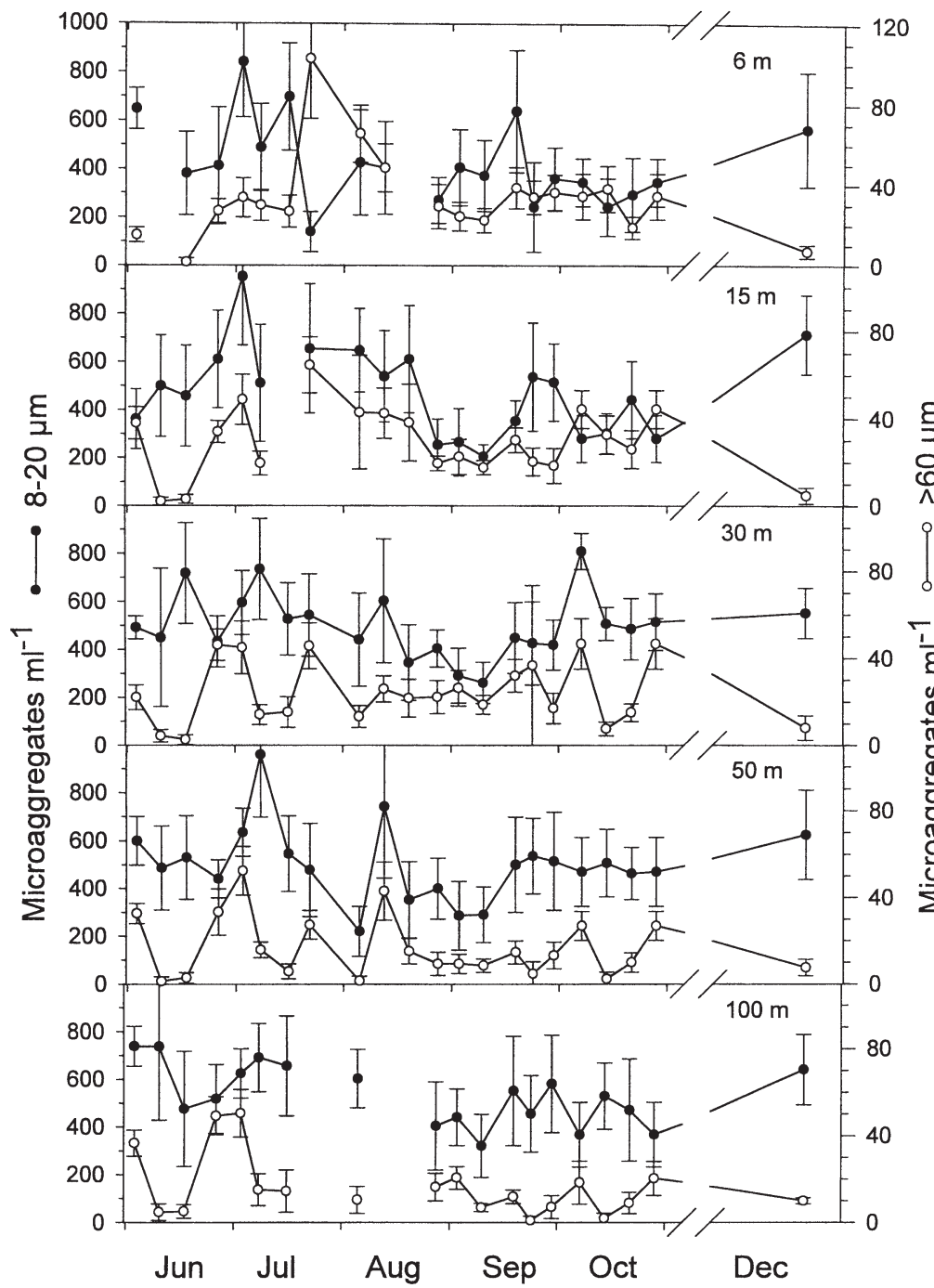

Fig. 3. Numbers of microaggregates in the size classes 8 to 20 and $>60 \mu \mathrm{m}( \pm \mathrm{SD})$ at $6,15,30,50$ and $100 \mathrm{~m}$ depths in Lake Constance between June and December 1996

specific for the $\alpha$-Proteobacteria. Possible reasons are discussed below. The cumulative proportion of all cells detected by the group-specific probes ranged from $60 \%$ of the cells detected by probe EUB338 for bacterial aggregates to $>95 \%$ of DAPI yellow particles, fragments and diatom aggregates (Table 5).

\section{DISCUSSION}

\section{Spatio-temporal dynamics of MA}

Our results show that the temporal dynamics of the DAPI-stained MA of the various size classes were independent of those of the phytoplankton. Only MA $>60 \mu \mathrm{m}$ at $6 \mathrm{~m}$, though accounting for $<5 \%$ of total MA at this depth, was significantly correlated to biomasses of Dinobryon sp. and the dinoflagellate Ceratium hirundinella. At $15 \mathrm{~m}$ and below, MA dynamics of various size classes covaried only among each other, and at 30 and $50 \mathrm{~m} \mathrm{MA}$ of the size class 20 to $60 \mu \mathrm{m}$ also with TEP. Further, MA abundances did not decrease systematically with depth. Hence, these results suggest that phytoplankton-related processes were not a direct source of the DAPI-stained MA and imply that other processes were controlling the spatio-temporal dynamics of these MA. With respect to TEP, our results also do not provide clearcut evidence that their abundance is controlled directly by phytoplankton-related processes.

Many reports, however, have documented that the dynamics of TEP, either occurring as free particles or associated with cells, are closely correlated to growth

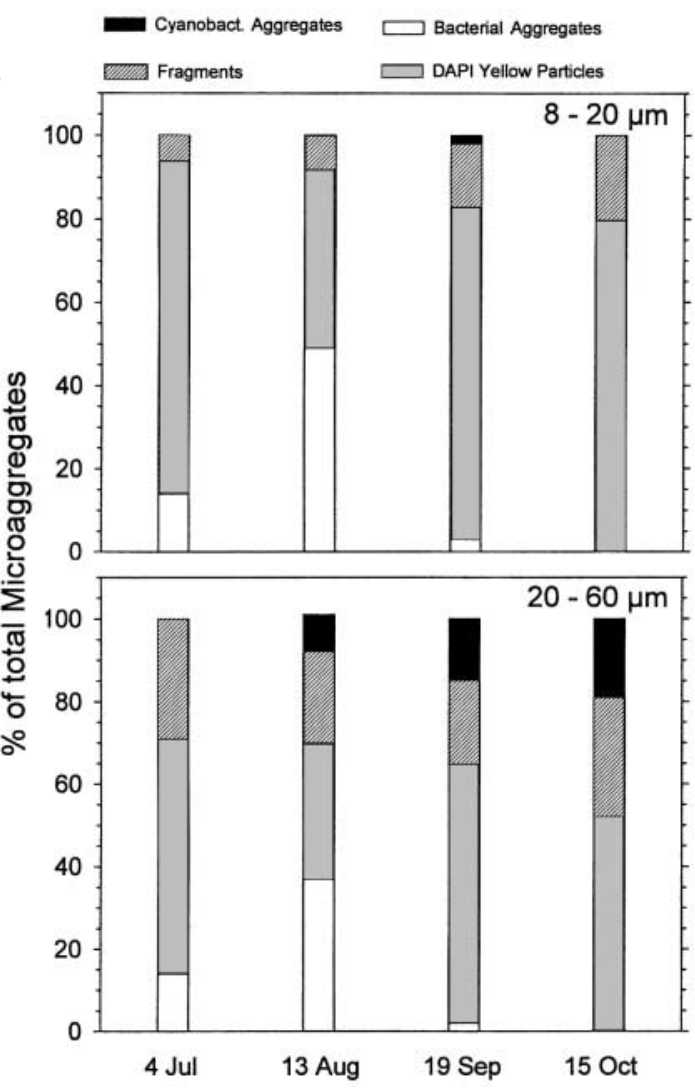

Fig. 4. Component particle composition of DAPIstained microaggregates in the size classes 8 to 20 and 20 to $60 \mu \mathrm{m}$ on 4 July, 13 August, 19 September and 15 October 1996 in Lake Constance. Data from different depths were pooled 
Table 4. Proportions of various types and size classes of DAPI-stained MA colonized by bacteria (\% of total MA of the respective category and size class). nd: not detected

\begin{tabular}{|c|c|c|c|c|c|c|c|c|}
\hline \multirow[t]{2}{*}{ Type } & \multicolumn{2}{|c|}{$4 \mathrm{Jul}$} & \multicolumn{2}{|c|}{13 Aug } & \multicolumn{2}{|c|}{19 Sep } & \multicolumn{2}{|c|}{15 Oct } \\
\hline & 8 to $20 \mu \mathrm{m}$ & 20 to $60 \mu \mathrm{m}$ & 8 to $20 \mu \mathrm{m}$ & 20 to $60 \mu \mathrm{m}$ & 8 to $20 \mu \mathrm{m}$ & 20 to $60 \mu \mathrm{m}$ & 8 to $20 \mu \mathrm{m}$ & 20 to $60 \mu \mathrm{m}$ \\
\hline DAPI yellow particles & 51.3 & 75.4 & 60.5 & 90.3 & 73.8 & 98.4 & 73.8 & 96.2 \\
\hline Fragments & 66.7 & 72.4 & 75.0 & 100.0 & 66.7 & 55.0 & 80.0 & 86.2 \\
\hline Cyanobacterial MA & nd & nd & nd & nd & 50.0 & 93.3 & nd & 94.7 \\
\hline
\end{tabular}

dynamics of diatoms (e.g., Alldredge et al. 1993, Kiørboe et al. 1994, Passow et al. 1994, Logan et al. 1995, Grossart et al. 1997). In fact, Logan et al. (1995) and Grossart et al. (1997) showed that in Lake Constance high numbers of TEP can lead to rapid aggregation and sedimentation of diatom blooms in spring and summer but that during the decomposition of diatoms, TEP associated with the cells are released as free TEP, thus leading to a second aggregation and sedimentation event toward the end of a bloom. The time course and absolute numbers we found are similar to previous reports regarding Lake Constance (Logan et al. 1995, Grossart et al. 1997) but lower than in Lake Kinneret and a Danish eutrophic lake, where TEP were produced from decaying filamentous cyanobacteria (Grossart et al. 1998, Worm \& Søndergaard 1998). With respect to TEP and dinoflagellates, Alldredge et al. (1998) reported that marine dinoflagellates did not produce TEP but did produce some other mucus-like and sticky material that was not stained by alcian blue. The peaks of TEP abundance in our study did not coincide with that of dinoflagellates, possibly because
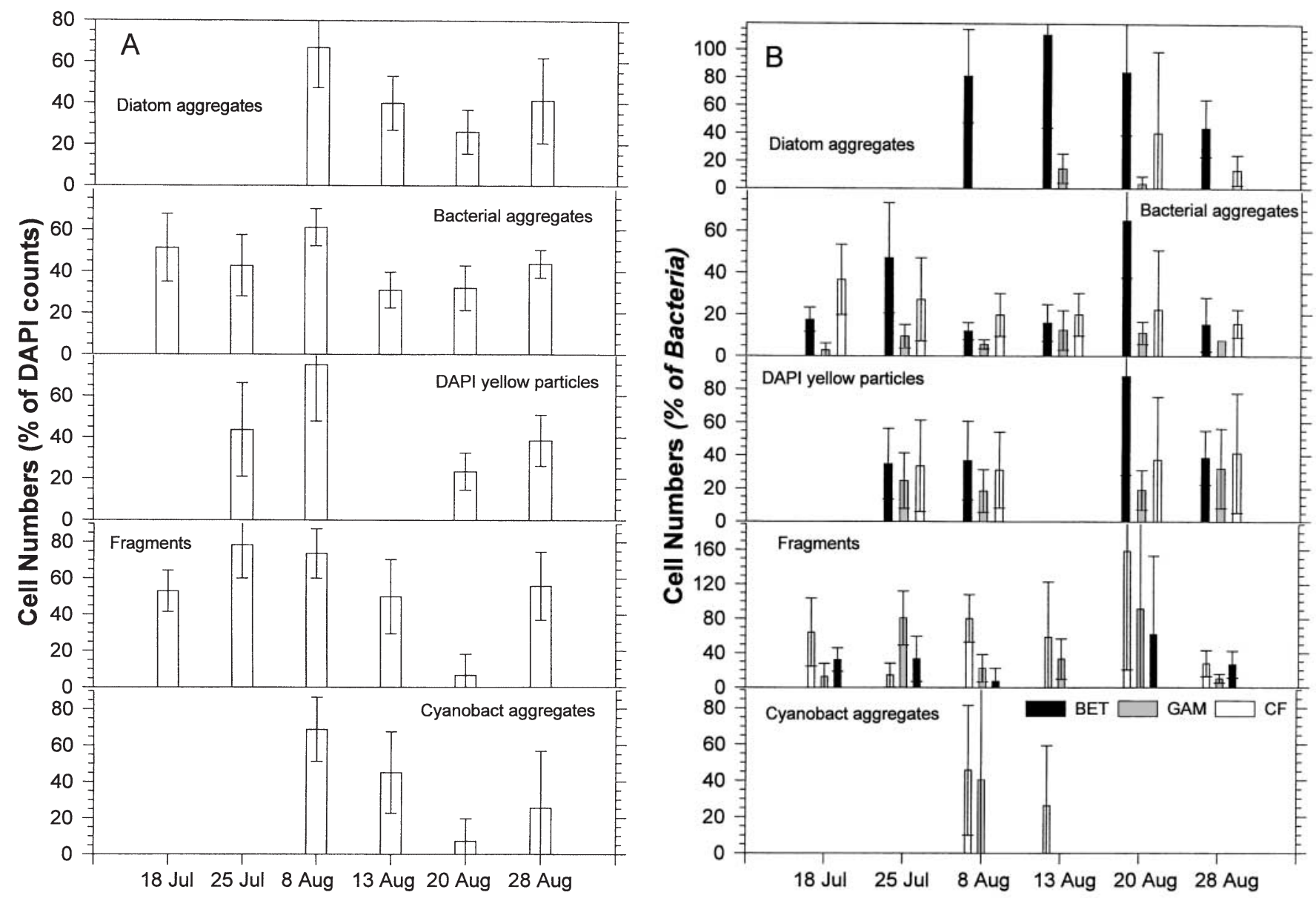

Fig. 5. Composition of the bacterial community on various types of microaggregates at $15 \mathrm{~m}$ determined by in situ hybridization with rRNA-targeted fluorescent oligonucleotide probes specific for Bacteria (EUB338; A), $\beta$ - and $\gamma$-Proteobacteria (BET42a, GAM42a), and cells of the Cytophaga/Flavobacteria cluster (CF319a, B) 
Table 5. Colonization of various types of DAPI-stained MA by Bacteria detected by probe EUB338, $\beta$-Proteobacteria detected by probe BET42a, $\gamma$-Proteobacteria detected by probe GAM42a, and cells of the Cytophaga/Flavobacteria cluster detected by probe CF319a. Given are mean percentages \pm SD of DAPI-stainable cells and of Bacteria for all samples analyzed. N: numbers of samples analyzed; nd: no data; Total bact: sum of $\beta$ - and $\gamma$-Proteobacteria and Cytophaga/Flavobacteria

\begin{tabular}{|c|c|c|c|c|c|c|c|c|c|c|c|c|}
\hline \multirow[t]{2}{*}{ Type of MA } & \multicolumn{2}{|c|}{ Bacteria } & \multicolumn{3}{|c|}{$\beta$-Proteobacteria } & \multicolumn{3}{|c|}{$\gamma$-Proteobacteria } & \multicolumn{3}{|c|}{ Cytophaga/Flavobacteria } & \multirow{2}{*}{$\begin{array}{l}\text { Total } \\
\text { bact } \\
\text { \%EUB }\end{array}$} \\
\hline & $\%$ DAPI & $\mathrm{N}$ & $\%$ DAPI & $\%$ EUB & $\mathrm{N}$ & $\%$ DAPI & $\%$ EUB & $\mathrm{N}$ & $\%$ DAPI & $\%$ EUB & $\mathrm{N}$ & \\
\hline Bacterial aggregates & $43.9 \pm 15.0$ & 9 & $10.1 \pm 5.7$ & $25.7 \pm 17.3$ & 9 & $3.9 \pm 1.7$ & $10.6 \pm 5.8$ & 8 & $11.3 \pm 5.7$ & $23.0 \pm 6.4$ & 7 & 59.3 \\
\hline DAPI yellow particles & $44.6 \pm 16.9$ & 5 & $18.6 \pm 5.0$ & $40.9 \pm 20.6$ & 5 & $8.7 \pm 3.9$ & $18.6 \pm 9.0$ & 6 & $19.7 \pm 5.2$ & $36.9 \pm 3.9$ & 4 & 94.6 \\
\hline Fragments & $55.7 \pm 29.7$ & 9 & $29.0 \pm 22.0$ & $60.8 \pm 41.2$ & 9 & $19.7 \pm 17.8$ & $40.1 \pm 27.8$ & 9 & $14.6 \pm 7.7$ & $32.9 \pm 16.1$ & 6 & 133.8 \\
\hline Diatom aggregates & $47.4 \pm 18.8$ & 6 & $31.6 \pm 13.1$ & $60.4 \pm 27.3$ & 6 & $3.4 \pm 2.5$ & $11.4 \pm 5.6$ & 3 & $8.1 \pm 2.5$ & $26.8 \pm 13.4$ & 2 & 98.6 \\
\hline Cyanobacterial aggregates & $44.2 \pm 25.5$ & 5 & $21.7 \pm 9.9$ & $36.0 \pm 9.8$ & 2 & 27.8 & 40.4 & 1 & nd & nd & & nd \\
\hline
\end{tabular}

mucus-like material of dinoflagellates was not stained by alcian blue. Abundances of lake snow aggregates in the year of the present study in Lake Constance were highest during July and not toward the end of the diatom bloom in August (Schweitzer et al. 2001), suggesting that TEP did not trigger aggregation and sedimentation of this bloom. The fact that TEP abundances at greater depths also exhibited a few peaks with strong declines to a background level of $<400 \mathrm{ml}^{-1}$ thereafter indicates a rapid release of free TEP from decomposing POM and a rapid decomposition and/or scavenging of TEP at these depths.

The fact that DAPI-stained MA at $6 \mathrm{~m}$ correlated to the biomasses of chrysophytes and Ceratium hirundinella only in the size class $>60 \mu \mathrm{m}$ suggests that formation of $\mathrm{MA}$ in the smaller size classes was not directly related to living or senescent phytoplankton. It has been reported from marine environments that zooplankton may also affect dynamics of TEP and macroscopic aggregates by ingestion and mechanical disruption (Dilling \& Alldredge 2000, Passow \& Alldredge 2000). Hence, zooplankton may also have contributed to controlling MA abundance in Lake Constance even though we assume that this was only a minor effect. The observation that MA abundances in the size classes $<60 \mu \mathrm{m}$ did not decrease systematically with depth, however, supports our suggestion that phytoand zooplankton affected their dynamics only a little. At greater depths, the dynamics of MA of the mediumsize class and $>60 \mu \mathrm{m}$, and that of TEP, excluding peak events, covaried fairly closely. This observation suggests that in the hypolimnion with low concentrations of suspended POM and low microbial activities MA persisted for quite a while and were slowly decomposed or scavenged. As a conclusion we assume that the DAPI-stained MA in the size class $>60 \mu \mathrm{m}$ at $6 \mathrm{~m}$ were mainly decomposition products of chrysophytes and dinoflagellates and at greater depths older decomposition products of POM of various origins. However, we note that the abundance of DAPI-stained MA $>60 \mu \mathrm{m}$ was 10 times lower than that of TEP and 5 times lower than that of the smaller DAPI-stained MA. Hence, TEP was generally much more important as decomposition products of fairly fresh phytodetritus. Because we also identified DAPI-stained MA consisting of diatom frustules we can not rule out a certain overlap of assessing TEP and MA > $60 \mu \mathrm{m}$ (see below). We further assume that the smaller sized DAPI-stained MA at all depths were older decomposition products of disintegrating POM and not source particles of macroscopic aggregates. This assumption is further supported by the bacterial colonization of the MA (see below).

We cannot rule out the possibility that there was a certain overlap of assessing DAPI-stained MA and TEP and thus of the occurrence of autocorrelations. DAPI yellow particles and phytoplankton and zooplankton fragments, however, were never stained by alcian blue and thus not counted as TEP. Diatom aggregates, taken into account for their bacterial colonization but not for the enumeration of DAPI-stained MA, were stained by alcian blue. However, because they were not exclusively composed of TEP, they were classified as particle-associated TEP, which was not considered in the enumeration of free TEP. Hence, we do not think that our results are biased by an overlap in assessing both types of MA and that the sum of both types of MA roughly equaled the total number of MA in Lake Constance.

The DAPI-stained MA were dominated by DAPI yellow particles and fragments mainly of phytoplankton but also of zooplankton origin. Bacterial and cyanobacterial aggregates occurred at lower numbers and irregularly and were, therefore, not as generally important as the other 2 types of MA. From August until October, however, macroscopic aggregates consisting of cyanobacterial colonies also occur in Lake Constance (Grossart \& Simon 1993, Grossart et al. 1997). Thus, we assume that there is a more direct relationship between the occurrence of cyanobacterial MA and macroscopic aggregates, and free TEP (see above), in particular because cyanobacterial macro- 
scopic aggregates do not sink out of the water column but are decomposed in the upper $25 \mathrm{~m}$.

Mostajir et al. (1995a) described a class of microparticles $<20 \mu \mathrm{m}$ occurring in Mediterranean coastal waters, stained yellow by DAPI, which appear fairly similar to the DAPI-stained MA $<60 \mu \mathrm{m}$ we found, being most similar to our DAPI yellow particles. The abundance of the Mediterranean particles in the size classes 5 to $20 \mu \mathrm{m}$ was in the range of 10 to $400 \mathrm{ml}^{-1}$ and numbers decreased with increasing size. As in the present study, the authors did not find a continuous decrease with depth and poor relationships of these particles to phytoplankton parameters were observed. Mostajir et al. (1995a) postulated that these particles may have formed from dissolved organic matter by bubbling, egestion by protozoans, or by disintegration of larger aggregates. The Coomassie brilliant bluestainable and thus protein-containing microparticles Long \& Azam (1996) described seem to be quite different from the ones we found. Ninety percent of these particles were $<10 \mu \mathrm{m}$; their abundance covaried vertically with chlorophyll and was higher than the abundance of TEP. The numbers of these particles also varied more than those of the DAPI-stained MA that Mostajir et al. (1995a) and ourselves report on. The role of Coumassie brilliant blue-stainable microparticles in aggregate formation has not yet been examined.

\section{Bacterial colonization of MA}

The majority of DAPI-stained MA was colonized by bacteria and those in the size class 20 to $60 \mu \mathrm{m}$ to a greater extent than those in the smaller size class with a proportion of at least $72 \%$ except on 19 September. The intense bacterial colonization in particular of the aggregates 20 to $60 \mu \mathrm{m}$ in size is also evident from the fact that on the 4 dates when the various types of MA were examined often $>90 \%$ of them harbored bacteria. The number of bacteria per aggregate increased with the aggregate size but we did not find significant differences among the various types of aggregates at various depths. We did not enumerate the bacteria on TEP but according to published data we assume that the bacterial colonization of the DAPI-stained MA and TEP was not significantly different. The numbers of bacteria per MA we found are in the same range as those determined on other types of MA such as TEP and Coomassie blue-stained particles (Passow \& Alldredge 1994, Long \& Azam 1996, Worm \& Søndergaard 1998). Total bacterial numbers on the MA, however, may have been up to 2-fold higher provided that some MA are opaque such that they might be incompletely accessible to microscopic examination of their bacterial colonization. This inaccessibility to microscopic examination may also be a reason why a certain fraction of MA did not appear to be colonized by bacteria at all. Berger et al. (1996) also found microparticles not colonized by any bacteria.

Total numbers of bacteria on DAPI-stained MA in Lake Constance accounted for only $<3.5 \%$ of total planktonic bacteria. If we assume that the size of TEP was similar to that of the other MA and that TEP harbor similar numbers, this would roughly double the total number of MA-associated bacteria to $<7 \%$. This number is still low indicating the minor contribution of bacteria on MA to total bacterial numbers. The contribution of this bacterial fraction to the total turnover of labile dissolved organic matter and total bacterial biomass production presumably is higher and may account for up to $20 \%$ of total bacterial biomass production because particle-associated bacteria have been shown to exhibit higher cell-specific rates of polymer hydrolysis, uptake of amino acids and biomass production than free-living bacteria (Simon 1985, 1987, Irriberri et al. 1987, Hoppe 1991, Grossart \& Simon1998a, Ploug \& Grossart 1999). MA-associated bacteria, however, constitute a major proportion of total particle-associated bacteria in Lake Constance. MA and lake snow aggregates, constituting the majority of detrital POM in Lake Constance, harbor $<7 \%$ and $<5 \%$ of total bacteria, respectively (see above, Grossart \& Simon 1993, 1998a), showing that MA harbor more than $50 \%$ of total particle-associated bacteria. These numbers fit surprisingly well with the mean proportion of total particle-associated bacteria in Lake Constance of $<12 \%$ determined on particles retained on $3 \mu \mathrm{m}$ Nuclepore filters (Simon 1987).

The analysis of the composition of the bacterial community on DAPI-stained MA by fluorescent in situ hybridization showed that usually $\beta$-Proteobacteria and cells of the Cytophaga/Flavobacteria cluster dominated. The detection rate of Bacteria by probe EUB338 was variable but on average was between 44 and $56 \%$ of the DAPI counts. This detection rate is in the same range as that reported for free-living bacteria in lacustrine but below that reported for some marine environments and for lake snow-associated bacteria (Weiss et al. 1996, Pernthaler et al. 1998, Glöckner et al. 1999, Simon et al. 1999, Schweitzer et al. 2001). $\beta$-Proteobacteria alone dominated diatom aggregates and in some cases also fragments. This class of Proteobacteria also often dominates lake snow aggregates of an age of at least $3 \mathrm{~d}$, when they release dissolved amino acids into the surrounding water (Weiss et al. 1996, Grossart \& Simon 1998a, Schweitzer et al. 2001). Hence, the dominance of $\beta$-Proteobacteria on diatom MA suggests that they also are at least a few days old and that dissolved amino acids are released. As mentioned above, they may be decomposition stages of lake snow aggregates 
but may also have formed directly from decaying diatoms without subsequent aggregation into larger aggregates. On most other MA, $\beta$-Proteobacteria were also abundant but together with bacteria of the Cytophaga/Flavobacteria cluster. Bacteria of this cluster occur on 3 to $5 \mathrm{~d}$ old lake snow aggregates and with increasing proportions at increasing depth and age (Schweitzer et al. 2001). They are known to be able to degrade a variety of complex polymers including resistant carbohydrates (Reichenbach 1992). Therefore, we assume that the MA colonized by bacteria of the Cytophaga/Flavobacteria cluster, besides $\beta$-Proteobacteria, constitute more refractory detrital POM. Cells of the Cytophaga/Flavobacteria cluster, together with $\beta$ Proteobacteria, were also relatively abundant on bacterial aggregates. Hence, these aggregates may be microcolonies disrupted from disintegrating larger aggregates or may be aggregated microcolonies of free-living bacterial origin. The community of freeliving bacteria in Lake Constance often is also dominated by $\beta$-Proteobacteria and cells of the Cytophaga/Flavobacteria cluster (Zwisler \& Simon unpubl. data).

An interesting observation was that $\gamma$-Proteobacteria were abundant only on fragments composed of the remains of Dinobryon spp. and of zooplankton origin but on no other type of MA. They also constitute only minor proportions of the bacterial community on lake snow aggregates (Weiss et al. 1996, Schweitzer et al. 2001). $\gamma$-Proteobacteria are known to be adapted to high concentrations of readily available organic matter and to outcompete $\beta$-Proteobacteria when growing under these conditions (Wagner et al. 1993). Therefore, the MA mentioned above either comprise such readily available organic matter or are colonized by types of $\gamma$ Proteobacteria with physiological properties different from most other members of this phylogenetic lineage. In order to answer this question, the physiology of these bacteria has to be studied in pure culture and their population dynamics on these types of MA must be studied by species-specific probes.

It was intriguing that we did not detect any signal of $\alpha$-Proteobacteria on MA. We have no indication of unreliable batches of oligonucleotides because they were applied successfully to lake snow aggregates (Schweitzer et al. 2001). We also can rule out non-stringent hybridization conditions because this probe was used in a double-labeling procedure together with the probe EUB338, which always gave positive signals. Thus, even though we cannot rule out completely methodological biases, we assume that the absence of $\alpha$-Proteobacteria from MA is a further indication that they were older decomposition stages of detrital POM. $\alpha$-Proteobacteria were shown to be most abundant on lake snow aggregates not older than $2 \mathrm{~d}$, and their proportions decreased substantially with increasing age of the aggregates (Weiss et al. 1996, Schweitzer et al. 2001). They were also dominant on freshly formed diatom MA during the early aggregation phase (Knoll et al. 2001). Hence, we assume that the MA we studied were older than a few days, so that $\alpha$-Proteobacteria had already disappeared.

All group-specific probes together accounted for $>95 \%$ of the bacteria detected by the EUB338 probe except for bacterial aggregates, on which only $59 \%$ were detected. Thus, we detected the vast majority of Bacteria on all types of MA except on bacterial aggregates. Missing some $\alpha$-Proteobacteria on any type of MA and even a greater proportion on bacterial aggregates would not change the general results. In some cases when detection rates $>100 \%$ of Bacteria by the group-specific probes were recorded, proportions of Bacteria detected by EUB338 were particularly low.

One problem with the analysis of the composition of bacterial communities on MA was the high standard deviation of the replicate counts, which often made it difficult to detect significant differences among the various types of MA and sampling dates. Because MA, but often also macroscopic aggregates, vary greatly in size and structure, a high standard deviation of any measurement on aggregates is inherent in these studies (e.g., Alldredge \& Gotschalk 1989, Passow et al. 1994, Grossart \& Simon 1998a). A lower standard deviation would improve the validity of the results but certainly would not change their general meaning.

\section{Conclusion}

Our results show that TEP and DAPI-stained MA occurred in roughly similar proportions but with markedly different spatio-temporal dynamics. Dynamics of TEP and DAPI-stained MA >60 $\mu \mathrm{m}$ in the epilimnion were more directly related to phytoplankton whereas the smaller DAPI-stained MA throughout the water column appeared to be later decomposition stages of detrital POM. Most of the DAPI-stained MA were colonized by bacteria, and predominantly by $\beta$-Proteobacteria and bacteria of the Cytophaga/ Flavobacteria cluster, which is a further indication of the rather degraded stage of this class of detrital POM.

Acknowledgements. We would like to thank Christine Wünsch for assistance in the field and in enumerating TEP abundance, U. Gaedke for the phytoplankton data and B. Beese for chlorophyll data. We are most grateful to H. P. Grossart for stimulating discussions and valuable comments on an earlier version of this manuscript. This work was funded by grant Si 360/4-2 and by the Special Collaborative Program 'Cycling of Matter in Lake Constance' (SFB 248) from the Deutsche Forschungsgemeinschaft. 


\section{LITERATURE CITED}

Alldredge AL, Gotschalk C (1989) Direct observation of the mass flocculation of diatom blooms: characteristics, settling velocities and formation of diatom aggregates. DeepSea Res 36:159-171

Alldredge AL, Silver ML (1988) Characteristics, dynamics and significance of marine snow. Prog Oceanogr 20:41-82

Alldredge AL, Passow U, Logan BE (1993) The abundance and significance of a class of large transparent organic particles in the ocean. Deep-Sea Res 40:1131-1140

Alldredge AL, Passow U, Haddock SHD (1998) The characteristics and transparent exopolymer particle (TEP) content of marine snow formed from thecate dinoflagellates. J Plankton Res 20:393-406

Amann RI, Krumholz L, Stahl DA (1990) Fluorescent oligonucleotide probing of whole cells for determinative, phylogenetic, and environmental studies in microbiology. J Bacteriol 172:762-770

Berger B, Hoch B, Kavka G, Herndl GJ (1996) Bacterial colonization of suspended particles in the River Danube. Aquat Microb Ecol 10:37-44

Berman T, Parparov A, Simon M (1999) Carbon fluxes in limnetic seston: relative significance of respiration, solubilization and non-photosynthetic formation. Arch Hydrobiol Spec Issues Adv Limnol 54:77-90

Dilling L, Alldredge AL (2000) Fragmentation of marine snow by swimming macrozooplankton: a new process impacting carbon cycling in the sea. Deep-Sea Res 47:1227-1245

Gaedke U (1998) Functional and taxonomical properties of the phytoplankton community of large and deep Lake Constance: interannual variability and response to re-oligotrophication (1979-1993). Arch Hydrobiol Spec Issues Adv Limnol 53:119-141

Glöckner FO, Fuchs BM, Amann R (1999) Bacterioplankton composition of lakes and oceans: a first comparison based on fluorescence in situ hybridization. Appl Environ Microbiol 65:3721-3726

Grossart HP, Simon M (1993) Limnetic macroscopic organic aggregates (lake snow): abundance, characteristics, and bacterial dynamics in Lake Constance. Limnol Oceanogr 38:532-546

Grossart HP, Simon M (1998a) Bacterial colonization and microbial decomposition of limnetic organic aggregates (lake snow). Aquat Microb Ecol 15:127-140

Grossart HP, Simon M (1998b) Significance of limnetic organic aggregates (lake snow) for the sinking flux of particulate organic matter in a large lake. Aquat Microb Ecol 15:115-125

Grossart HP, Simon M, Logan B (1997) Formation of macroscopic organic aggregates (lake snow) in a large lake: the significance of transparent exopolymer particles (TEP), phyto- and zooplankton. Limnol Oceanogr 42:1651-1659

Grossart HP, Berman T, Pohlmann K, Simon M (1998) Occurrence and microbial dynamics of macroscopic organic aggregates (lake snow) in Lake Kinneret, Israel, in fall. Aquat Microb Ecol 14:59-67

Güde H, Gries T (1998) Phosphorus fluxes in Lake Constance. Arch Hydrobiol Spec Issues Adv Limnol 53:505-544

Herndl GJ (1992) Marine snow in the northern Adriatic Sea: possible causes and consequences for a shallow ecosystem. Mar Microb Food Webs 6:149-172

Hoppe HG (1991) Microbial extracellular enzyme activity: a new key parameter in aquatic ecology. In: Chróst RJ (ed) Microbial enzymes in aquatic environments. Springer Verlag, New York, p 60-83

Irriberri J, Unanue M, Barcina I, Egea L (1987) Seasonal vari- ation in population density and heterotrophic activity of attached and free-living bacteria in coastal waters. Appl Environ Microbiol 53:2308-2314

Kepkay PE (1994) Particle aggregation and the biological reactivity of colloids. Mar Ecol Prog Ser 109:293-304

Kiørboe T, Lundsgaard C, Olesen M, Hansen JLS (1994) Aggregation and sedimentation processes during a spring phytoplankton bloom: a field experiment to test coagulation theory. J Mar Res 52:297-323

Knoll S, Zwisler W, Simon M (2001) Bacterial colonization of early stages of limnetic diatom microaggregates. Aquat Microb Ecol 25:141-150

Koike I, Shigemitsu H, Kazuki T, Kogure K (1990) Role of submicrometer particles in the ocean. Nature 345:242-244

Logan BE, Grossart HP, Simon M (1994) Direct observation of phytoplankton, TEP and aggregates on polycarbonate filters using brightfield microscopy. J Plankton Res 16: 1811-1815

Logan BE, Passow U, Alldredge AL, Grossart HP, Simon M (1995) Mass sedimentation of diatom blooms as large aggregates is driven by coagulation of transparent exopolymer particles (TEP). Deep-Sea Res 42:203-214

Long RA, Azam F (1996) Abundant protein-containing particles in the sea. Aquat Microb Ecol 10:213-221

Manz W, Amann R, Ludwig W, Wagner M, Schleifer KH (1992) Phylogenetic oligonucleotide probes for the major subclasses of Proteobacteria: problems and solutions. Syst Appl Microbiol 15:593-600

Manz W, Amann R, Ludwig W, Vancanneyt M, Schleifer KH (1996) Application of a suite of 16S rRNA-specific oligonucleotide probes designed to investigate bacteria of the phylum cytophaga-flavobacter-bacteroides in the natural environment. Microbiology 142:1097-1106

Mostajir B, Dolan JR, Rassoulzadegan F (1995a) Seasonal variations of pico- and nano-detrital particles (DAPI yellow particles, DYP) in the Ligurian Sea (NW Mediterranean). Aquat Microb Ecol 9:267-277

Mostajir B, Dolan JR, Rassoulzadegan F (1995b) A simple method for the quantification of labile marine pico- and nano-sized detritus: DAPI yellow particles (DYP). Aquat Microb Ecol 9:259-266

Nagata T, Kirchman DL (1997) Roles of submicron particles and colloids in microbial food webs and biogeochemical cycles within marine environments. Adv Microb Evol 15: 81-103

Passow U, Alldredge AL (1994) Distribution, size and bacterial colonization of transparent exopolymer particles (TEP) in the ocean. Mar Ecol Prog Ser 113:185-198

Passow U, Alldredge AL (2000) Do transparent exopolymer particles (TEP) inhibit grazing by the euphausiid Euphausia pacifica? J Plankton Res 21:2203-2217

Passow U, Alldredge AL, Logan BE (1994) The role of particulate carbohydrate exudates in the flocculation of diatom blooms. Deep-Sea Res 41:335-357

Pernthaler J, Glöckner FO, Unterholzner S, Alfreider A, Psenner R, Amann R (1998) Seasonal community and population dynamics of pelagic Bacteria and Archaea in a high mountain lake. Appl Environ Microbiol 64:4299-4306

Ploug H, Grossart HP (1999) Bacterial production and respiration in suspended aggregates - a matter of the incubation method. Aquat Microb Ecol 20:21-29

Ploug H, Kühl M, Buchholz-Cleven B, Jørgensen BB (1997) Anoxic aggregates - an ephemeral phenomenon in the pelagic environment. Aquat Microb Ecol 13:285-294

Ploug H, Grossart HP, Azam F, Jørgensen BB (1999) Photosynthesis, respiration, and carbon turnover in sinking marine snow from surface waters of Southern California 
Bight: implications for the carbon cycle in the ocean. Mar Ecol Prog Ser 179:1-11

Reichenbach H (1992) The order Cytophagales. In: Balows A, Trüper HG, Dworkin M, Harder W, Schleifer KH (eds) The prokaryotes. Springer Verlag, New York, p 3631-3675

Schweitzer B, Huber I, Amann R, Ludwig W, Simon M (2001) $\alpha$ - and $\beta$-Proteobacteria control the consumption and release of amino acids on lake snow aggregates. Appl Environ Microbiol 67:632-645

Simon M (1985) Specific uptake rates of amino acids by attached and free-living bacteria in a mesotrophic lake. Appl Environ Microbiol 49:1254-1259

Simon M (1987) Biomass and production of small and large free-living and attached bacteria in Lake Constance. Limnol Oceanogr 32:591-607

Simon M, Bunte C, Schulz M, Weiss M, Wünsch C (1998) Bacterioplankton dynamics in Lake Constance (Bodensee): substrate utilization, growth control, and long-term trends. Arch Hydrobiol Spec Issues Adv Limnol 53: $195-221$

Simon M, Glöckner FO, Amann R (1999) Different community structure and temperature optima of heterotrophic

Editorial responsibility: Karel Šimek,

České Budějovice, Czech Republic picoplankton in various regions of the Southern Ocean. Aquat Microb Ecol 18:275-284

Smith DC, Simon M, Alldredge AL, Azam F (1992) Intense hydrolytic enzyme activity on marine aggregates and implications for rapid particle dissolution. Nature 359: 139-142

Snaidr J, Amann R, Huber I, Ludwig W, Schleifer KH (1997) Phylogenetic analysis and in situ identification of bacteria in activated sludge. Appl Environ Microbiol 63:2884-2896

Wells ML, Goldberg ED (1994) The distribution of colloids in the North Atlantic and Southern Ocean. Limnol Oceanogr 39:286-302

Wagner M, Amann R, Lemmer H, Schleifer KH (1993) Probing activated sludge with oligonucleotides specific for Proteobacteria: inadequacy of culture-dependent methods for describing microbial community structure. Appl Environ Microbiol 59:1520-1525

Weiss P, Schweitzer B, Amann R, Simon M (1996) Identification in situ and dynamics of bacteria on limnetic organic aggregates (lake snow). Appl Environ Microbiol 62:1998-2005

Worm J, Søndergaard M (1998) Alcian blue-stained particles in a eutrophic lake. J Plankton Res 20:179-186

Submitted: March 14, 2001; Accepted: August 12, 2001 Proofs received from author(s): October 2, 2001 